\title{
Industry Reports
}

\section{Industrial Biotechnology-An Industry at an Inflection Point}

Nathan Danielson, Sarah McKay, ${ }_{1}^{2}$ Paul Bloom, ${ }_{1}^{3}$ Jennifer Dunn, ${ }^{4,5}$ Neal Jakel, ${ }^{6}$ Timothy Bauer, ${ }^{6}$ John Hannon, Michael C. Jewett, ${ }^{4,5}$ and Brent Shanks ${ }^{8}$

\author{
${ }^{1}$ BioCognito, Pleasanton, CA, USA \\ ${ }^{2}$ National Corn Growers Association, St. Charles, MO, USA \\ ${ }^{3}$ Archer Daniels Midland Co., Decatur, IL, USA \\ ${ }^{4}$ Northwestern University, Evanston, IL, USA \\ ${ }^{5}$ Northwestern Argonne Institute of Science and Engineering, \\ Evanston, IL, USA \\ ${ }^{6}$ Fluid Quip Technologies, Cedar Rapids, IA, USA \\ ${ }^{7}$ Vertimass, Irvine, CA, USA \\ ${ }^{8}$ lowa State University, Ames, IA, USA
}

\begin{abstract}
Industrial biotechnology is poised for dramatic growth. A confluence of consumer demand; attractive feedstock quantity, quality, and price; and technical innovation has created a perfect situation for the industry to significantly expand. Since the 2004 Werpy and Peterson paper, "Top Value Added Chemicals from Biomass," the biobased manufacturing industry and the technologies that make these processes and products possible has evolved significantly. ${ }^{1}$ New technology continues to advance, and there is increasing consumer and industry demand for biobased materials. Paired with increasing on-farm efficiency and sustainability considerations, these are all factors that are driving the bioeconomy forward. This paper reviews these factors and illustrates where the technology can head, identifying opportunities for utilizing corn-based sugars as a feedstock for near-term, high-impact products in the biorenewable space. Furthermore, this paper suggests what policies should be considered to move the industry towards the future.
\end{abstract}

Keywords: biomaterials, policy, feedstocks

\section{Introduction}

I n 2004, Werpy and Petersen published "Top Value Added Chemicals from Biomass", , which described biological and chemical conversion processes utilizing sugars from biomass that could produce twelve building block che- micals. This paper spurred much interest and development in research, technology, and infrastructure in the biorenewables space.

One learning from the past 16 years is that renewable materials can and must compete on price and out-compete on performance and sustainability. ${ }^{2}$ We intend for this paper to provide an overview of where we are at today in this effort to develop products that meet these criteria and what is on the horizon. As the goal of this paper is to present products with near-term impact, we intend to focus on commercially available feedstocks and technologies that could reach the market within five to seven years. Finally, we recommend research priorities, innovations, and policy directions that should drive new products to market and increase interest in this sector.

We are witnessing an important alignment of factors that will support additional biorenewables reaching the market. These include continued growth in sustainable feedstock production efficiencies, increasing feedstock production and sustainability, consumer interest, and technological advances which continue to drive progress in the renewable products space.

Globally, farmers continue to adopt innovative production practices, improving sustainability and economic efficiency. These practices include improved genetics, reduced and no-till practices, cover crops, precision agriculture, and integration of technologies that optimize nutrient management. This is particularly true of US farmers. ${ }^{3}$ As a result, US production continues to improve year-over-year, producing more crops with fewer inputs and creating opportunities beyond food, feed, and fuel products.

At the same time, consumers worldwide continue to demand additional biobased products. In a recent Kearney study, $78 \%$ of consumers believe companies could be doing more to improve environmental outcomes, and since $2019,11 \%$ more consumers reported shifting their purchases of core products based on environmental claims. ${ }^{4}$ This confluence of commercially sustainable renewable feedstocks and consumer demand represents an extremely exciting opportunity for all stakeholders in the biomaterials industry. As agencies, innovators, and companies all look toward more sustainable solutions and applications relevant to their industry, this paper identifies opportunities for utilizing corn-based sugars in the biorenewables space.

While many of the compounds described in this paper can be produced from a variety of feedstocks, there is tremendous opportunity to meet society's needs on an accelerated timeline

(c) Nathan Danielson et al., 2020; Published by Mary Ann Liebert, Inc. This Open Access article is distributed under the terms of the Creative Commons License (http://creativecommons.org/licenses/by/4.0), which permits unrestricted use, distribution, and reproduction in any medium, provided the original work is properly cited. 


\section{INDUSTRY REACHES INFLECTION POINT}

\section{Table 1. Chemicals Listed in Top Value-Added Chemicals from Biomass and How They Have Progressed}

Toward Commercialization

\begin{tabular}{|c|c|c|c|}
\hline CHEMICAL & STATUS & NOTES/COMPANIES PURSUING & USES \\
\hline 3-Hydroxybutyrolactone & Early research and development & & Polymers, pharma precursor \\
\hline 3-Hydroxypropionic acid & $\begin{array}{l}\text { Significant development, currently } \\
\text { not commercial }\end{array}$ & $\begin{array}{l}\text { OPX, Novozymes Cargill and BASF for polyacrylates, } \\
\text { DOE efforts to convert to acrylonitrile }\end{array}$ & Intermediate \\
\hline Aspartic Acid & Limited research & & Nutrition, sweeteners \\
\hline Furan dicarboxylic acid & Significant commercial activity & ADM and DuPont, Annikki & Packaging polymers \\
\hline Glycerol & Commercial & ADM for PG, Solvay and others for epichlorohydrin & intermediate, humectant \\
\hline Glutamic acid & Commercialized for food uses & Ajinomoto others & Flavor \\
\hline Glucaric acid & Commercial & Rivertop (left market), Kalion & corrosion inhibitor, detergent \\
\hline Itaconic acid & Commercialized & Itaconix & Stabilizers and detergents \\
\hline Levulinic acid & Commercialized & GF Biochemicals & Solvents and intermediates \\
\hline Sorbitol & Commercialized & Many (Roquette, ADM, Sorbitol) & Sweeteners \\
\hline Succinic acid & Commercialized & $\begin{array}{l}\text { Many, some of which have left } \\
\text { market-BASF, Roquette, DSM }\end{array}$ & Polymers \\
\hline $\begin{array}{l}\text { 5-Carbon Sugar alcohols } \\
\text { (Xylitol, arabinitol) }\end{array}$ & Commercialized & Via hydrogenation & Sweeteners \\
\hline
\end{tabular}

when we separate product development from feedstock development risk. To this end, we will consider corn-derived sugars a representative feedstock throughout this paper.

As we look to the future, it is worth revisiting the "Top Value" molecules. There has been good progress on many of these molecules, as shown in Table 1.

\section{Technology Changes}

Over the past two decades, technology to bring industrial biotechnology products to market has advanced dramatically. For example, the cost to sequence a human genome in 2004 was between \$20-25 million, compared to less than $\$ 1,000$ today, according to the National Human Genome Research Institute. ${ }^{5}$ Newly developed techniques, such as CRISPR, allow for rapid and exquisite precision in genetic engineering. Metabolic pathways continue to be elucidated and enzyme engineering is now common practice. Robotics and microfluidics allow us to exponentially increase the number of experiments we can conduct while simultaneously reducing the cost per experiment. These new technologies generate unprecedented amounts of data that can now be processed and understood using artificial intelligence.

Synthetic biology is increasing the range of products that whole cells can economically produce. Also, novel materials are being developed to generate chemical catalysts having improved performance in biomass reactions. Importantly, significant advancements are being made in blending the best of biology and chemistry to create new opportunities for renewables. ${ }^{6}$ A good example of this is the conversion of bio-based 3hydroxypropionic acid to carbon fiber using chemical catalysis. ${ }^{7}$
These new conversion techniques have the potential to be more environmentally sustainable and economically advantaged.

New crop production technologies continue to drive efficiency. Between 2004 and 2018, corn yields increased by $10 \%$ per hectare. This yield increase occurred while simultaneously decreasing inputs of nitrogen by $13 \%$, phosphorus by $14 \%$, and potassium by $20 \%$ for each metric ton of corn produced. ${ }^{8}$ These improvements are driven by better management practices, precision agriculture and improved genetics. Going forward, further reductions may be achieved by improving the microbiome as indicated by work done by new and innovative companies such as Pivot Bio, ${ }^{9}$ which has a microbe that is able to fix nitrogen for non-legumes. These technologies are both accelerating and tend to be cumulative, so we anticipate a continued improvement and optimization of crop production sustainability.

Significant new manufacturing infrastructure exists. Since 2004, global production of biobased ethanol has increased from 40 to 109 billion liters. This represents an important evolution in rural economies, from producing mostly food to production of fuels, industrial chemicals, and high-value feed products. Production of biofuels has resulted in the construction of entirely new infrastructure and supply chains for fuels. While biorefineries existed in 2004, there were far fewer than now. Today there are 210 ethanol plants in 27 states in the US alone, many of which are expanding their product lines. ${ }^{10}$

Biorefineries are evolving. New processes are being implemented that allow diversification of revenue streams. This is not dissimilar to the evolution of the petrochemical industry, which started with just a few products and now produces thousands. New technologies, currently being deployed in biorefineries, allow the separation of high-purity feedstock streams-oils, 
proteins, starch/sugar, and fiber. This will enable additional high-value products. Just as a clean stream of ethylene allows polyethylene production in refineries, so too will clean sugars, proteins, lipids and fiber allow for the production of a wide range of food, feed, fuel and chemicals from biorefineries.

\section{Advantaged Molecules We Can Make Today}

A strength of industrial biotechnology is the broad array of chemical products that could in principle be synthesized. Due to the functionality present in biomass-derived feedstocks, the breadth of these potential products is more extensive than can be synthesized from hydrocarbon feedstocks. However, the chemical industry has been primarily developed from hydrocarbon feedstocks and as such the commercial products are known and their manufacturing technology mature. A challenge for industrial biotechnology is to determine the most promising chemical products to pursue for commercialization. In the absence of public policy or consumer preference to incentivize biobased chemicals, chemical products utilizing industrial biotechnology must generate known chemicals at lower cost than petrochemicals or create new chemicals that can provide unique performance in end use applications.

Table 2 shows biobased chemicals currently manufactured in significant quantities either directly or as further derivatives. ${ }^{11}$

\section{Table 2. Select Currently Produced Biobased Molecules}

\begin{tabular}{l|c|l|c}
$\begin{array}{c}\text { BIOBASED } \\
\text { CHEMICAL }\end{array}$ & $\begin{array}{c}\text { CAPACITY } \\
\text { (KTA) }\end{array}$ & FERMENTATION & CATEGORY \\
\hline ethanol & 80,800 & yes & 1 \\
\hline citric acid & 2000 & yes & 1 \\
\hline sorbitol & 1800 & no & 1 \\
\hline glycerol & 1500 & no & 1 \\
\hline lysine & 1100 & yes & 1 \\
\hline lactic acid & $>600$ & yes & 1 \\
\hline furfural & 360 & no & 1 \\
\hline sebacic acid & 200 & no & 1 \\
\hline xylitol & 190 & no & 1 \\
\hline propylene glycol & 120 & no & 1 \\
\hline itaconic acid & 90 & yes & 1 \\
\hline 1,3-propanediol & 77 & yes & 1 \\
\hline epichlorohydrin & 540 & no-derivative & 2 \\
\hline ethylene & 200 & no-derivative & 2 \\
\hline ethylene glycol & 175 & no-derivative & 2 \\
\hline Category mole & not & \\
\hline
\end{tabular}

${ }^{1}$ Category 1 molecules cannot be cost-effectively produced from hydrocarbons. Category 2 molecules have lower environmental footprints from biomass compared to production from hydrocarbons and may support comparable or slightly higher pricing than the equivalent petrochemical.
These molecules compete on both pricing and sustainability, therefore the selection of new biobased chemical targets would be expected to need similar advantages. The first category will likely require the introduction of novel chemicals uniquely enabled by biomass feedstocks and will need to be coupled with validation of their enhanced performance properties. The second type of biobased chemical will need to have their environmental footprint validated through life cycle analysis or through at least perceived benefit by the customer. Of these two categories, several of the emerging biobased chemicals, such as succinic acid and 2-5-furandicarboxylic acid, are examples of molecules uniquely accessible from biomass that can provide enhanced performance in end use applications.

Historically, the choice of target biobased molecules for development has been opportunistic rather than systematic, which was in contrast to the development of the petrochemical industry. More recently, strategies have begun to emerge for target selection that is more methodical. The idea of promising building block chemicals from carbohydrates was introduced in 2004, when a list of 12 possible intermediates was selected from 300 potential molecules. $^{2}$ (Table 1). The concept of building block molecules has been extended into a computational framework for exploring new intermediates. ${ }^{12}$ Utilizing a "constraintbased metabolic modeling" approach and three criteria (profit margin, market volume, and market size), a set of promising fermentations has been postulated. ${ }^{13}$

\section{Where the Technology Can Go}

There are currently vast numbers of biologically produced products. These include pharmaceuticals, enzymes, biofuels and solvents, nutrients including vitamins and supplements, and novel polymers. As new technologies are employed, they increase the diversity of products that can be produced through industrial biotechnology. Underpinning these technological innovations are systems biology tools, machine learning, and cellfree systems - each of which is set to help in rationally and predictably designing cellular functions for bioenergy applications. First, new omics technologies are increasing the tools available for industrial biotechnology. This has resulted in the identification of improved enzymes for conversion, an ongoing elucidation of metabolic pathways and the genetic engineering of production hosts which were heretofore impossible for industrial use. Second, machine learning is becoming more prevalent and will have an increasing impact. ${ }^{14}$ Third, datadriven, multiplexed cell-free systems are also accelerating biodiscovery and design. ${ }^{15-18}$ Beyond systems biodesign tools, traditional catalysts continue to improve, further expanding the opportunities for bioconversion. All of these improvements tend to work together to both increase product range while simultaneously driving down cost.

Enogen $^{\mathrm{TM}}$ corn represents a peek into the future of bioprocessing with enhanced enzymes. This corn has a thermostable alpha amylase that is produced by the plant as it grows but is only active during the high temperatures of liquefaction-the process by which starch is broken down into its structural sugar building blocks. Having the enzyme produced endogenously not only reduces the cost of purchasing enzyme, but improves sugar yield while decreasing both water and energy usage. ${ }^{19}$ This 
Table 3. Potential for Reducing Capital and Operational Expense as Well as Expanding What Can Be Produced in Novel Production Host Types or Using Cell-Free Systems

PRODUCTION HOST TYPE

Thermophilic

\begin{tabular}{l|l}
\hline Psychrophilic & cost separation of volatile products \\
\hline Halophilic & $\begin{array}{l}\text { Production of labile products or } \\
\text { production in labile media }\end{array}$ \\
\hline Acidophililes or alkaliphiles & $\begin{array}{l}\text { Reduced contamination, potential for } \\
\text { sea or brackish fermentation water }\end{array}$ \\
\hline Electrotrophic & $\begin{array}{l}\text { Reduced contamination, potential for } \\
\text { low cost separation }\end{array}$ \\
\hline Cell-free production & $\begin{array}{l}\text { Ability to convert electricity and } \mathrm{CO}_{2} \text { to } \\
\text { bio- materials. Additionally, may offer } \\
\text { way to utilize stranded electricity }\end{array}$ \\
\hline
\end{tabular}

approach has wide relevance to other feedstocks beyond corn, particularly those to which adding exogenous enzymes would be cost prohibitive.

Continuing further, extremophiles offer a number of potential benefits including expanded products; use of low-value feedstocks, brackish or seawater; and reduced capital and operational expenses (Table 3). A good example of the potential for extremophiles is the production of polyhydroxyalkanoates (PHA), which are naturally produced polymers that have significant potential as renewable biodegradable plastics. Chen et al. were able to produce $1.04 \mathrm{~g} / \mathrm{L} / \mathrm{h}$ and reach a final titer of $50.6 \mathrm{~g} / \mathrm{l}$ in 48 hours in a non-sterile fermentation using low-cost ingredients, tap water and the halophile Halomonas bluephagenesis TD01 as a production host. ${ }^{20}$ This effort demonstrates the potential to use extremophiles as production hosts in environments that inhibit contamination.

Additionally, electotrophic bacteria, which can use free electrons to directly reduce $\mathrm{CO}_{2}$, may offer a unique approach to convert renewable electricity to renewable fuels and chemicals. $\mathrm{Yu}$ and coworkers were able to demonstrate production of acetate, and both formate and acetate, at 58.2 and $63.2 \mathrm{mmol} / \mathrm{m}^{2} /$ day on carbon nanoparticles. This shows that building block chemicals can be produced using primarily $\mathrm{CO}_{2}$ and electricity. The US Department of Energy (DOE) is currently exploring using electrophilic bacteria to valorize $\mathrm{CO}_{2}$ from ethanol plants by converting it into high-value renewable products such as acrylonitrile and 1,3-PDO. ${ }^{21}$

Beyond living organisms, cell-free biomanufacturing systems are also emerging as a powerful opportunity to advance energy and chemical manufacturing capabilities. ${ }^{15,16}$ The key idea is that precise, complex biomolecular transformations can be conducted in crude cell lysates without intact cells, or in purified enzyme systems. This concept circumvents mechanisms that have evolved to facilitate species survival, bypasses limitations on molecular transport across the cell wall, and provides a sig- nificant departure from traditional, cell-based processes that rely on microscopic cellular "reactors." ${ }^{22}$ Several recent studies have demonstrated promise in both purified and crude extract systems.

Purified enzyme systems allow exquisite control of reaction conditions, substrate utilization, and pathway fluxes since the concentration and activity of every component is known. Recently, strategies for supplying and balancing reducing equivalents and ATP using a molecular purge valve and molecular rheostat have been implemented. These designs have led to cellfree biosynthesis of isobutanol and terpenes at high titers, with reactions that run for multiple days. ${ }^{23}$ Crude extract systems offer lower catalyst costs than purified systems and embedded capabilities (e.g., cofactor regeneration systems and long-lived biocatalytic activity). Strikingly, it has been shown that native pathways in crude extracts can fuel highly active heterologous metabolic conversions. For example, glycolysis in crude E. coli lysates can power the production of 2,3-butanediol (a platform chemical) with near theoretical yields, high titers $(>80 \mathrm{~g} / \mathrm{L})$, and ultrahigh productivities $(>10 \mathrm{~g} / \mathrm{L} / \mathrm{h}) .{ }^{16}$ Cell-free biosynthesis of styrene has also been shown, surpassing the highest published in vivo titer without processing steps by more than an order of magnitude. ${ }^{24}$ Toxic pretreated biomass hydrolysates can even be used as feedstocks. ${ }^{25}$ Taken together, these results set the stage for new sustainable manufacturing practices, including agile domestic bio-readiness capabilities, that provide economically viable alternatives to fossil fuel-derived chemicals.

Industrial biotechnology maturation will inevitably drive towards creating the most efficient and cost-effective processing solutions, which are not siloed to specific technical subareas. As an example, conversion technology will be driven not by a priori selection of biological or chemical conversion, but by development of the best solution. This maturation process can be seen in evolving efforts to more deliberately consider effective integration of biological and chemical catalysis. ${ }^{2}$

Given the vast and growing number of sustainable chemicals produced biologically and/or thermochemically, there are very few limitations on what can be produced. Regarding what should be produced, that will require understanding the balance of market demand and product margins.

\section{Life Cycle Analysis and Sustainability}

Life Cycle Analysis (LCA) has been widely used to characterize the sustainability of biofuels and bioproducts. ${ }^{26}$ LCA integrates the material and energy flows of a bioproduct from the farm to end-of-life, enabling a technology developer, policy maker, or consumer to understand which portions of that supply chain contribute most to metrics including life-cycle greenhouse gas (GHG) emissions, energy and water consumption, and air pollutant emissions. Further, when developed with consistent methodologies, bioproduct LCA results can be compared to LCA results of peer products made from fossil fuels. Based on that comparison, stakeholders can evaluate the relative merits of bioproducts compared to today's technologies.

Bioproduct LCAs can be quite complex, especially with detailed treatment of the feedstock development portion of the supply chain. Farmers can undertake any number of land 
management practices, for example, that can contribute to or detract from a bioproduct's sustainability as evaluated in an LCA. For example, planting of cover crops and application of manure can increase soil carbon and, in the latter case, potentially decrease $\mathrm{N}_{2} \mathrm{O}$ emissions through displacement of conventional fertilizer. ${ }^{27}$

Another element of complexity in bioproduct LCA is the treatment of co-products in a biorefinery. ${ }^{28}$ If a bioproduct is produced alongside a biofuel, an LCA practitioner must decide whether to adopt a co-product handling technique based on displacement or allocation by energy content, mass, or market value. The choice of this co-product handling technique can influence results to a great extent.

Finally, end-of-life treatment is another issue in bioproduct LCA that deserves scrutiny. A long-lived product like a polymer may sequester biogenic $\mathrm{CO}_{2}$ that the biomass it was made from contained. If this is the case, the net effect could be a zero or net negative bioproduct depending upon the supply chain steps that precede end of life. On the other hand, if the product is shortlived and degrades or is incinerated, the biogenic $\mathrm{CO}_{2}$ is rereleased to the atmosphere. This latter treatment, while resulting in higher GHG emissions, could reduce solid waste, another often-highlighted goal for pursuing plastics made from biomass. It should be noted, of course, that making plastics from biomass does not ensure biodegradability. The polymer itself must be designed to biodegrade. For example, polyethylene tere- phthalate (PET) made from biomass may offer GHG advantages but, at the end of life will be as persistent in the environment as PET made from fossil fuels. ${ }^{29}$ Producing PET from biomass, therefore, is unlikely to mitigate solid waste issues associated with the polymer but may offer a way to sequester atmospheric carbon if handled appropriately.

As mentioned above, LCA can be used to explore many metrics. Water consumption is very important as water scarcity becomes a growing issue of concern. Figure 1 highlights the variation in irrigation levels by state. ${ }^{30}$ Most states exhibit a high coefficient of variation in irrigation level, indicating the importance of incorporating irrigation data in LCAs to the finest spatial scale possible. The same can be said for fertilizer levels, which also are spatially dependent along with yield, soil carbon changes based on management practices, and other components of feedstock production.

Finally, the issue of land use and land-use change is a core component of biofuels and bioproducts. ${ }^{31}$ As demand for both rises, it is possible that international agricultural land could expand into grasslands, forests, and wetlands, all of which have inherent value and provide critical ecosystem services from carbon sequestration to mitigating the effects of climate change such as flooding. Many certification strategies for bioproducts, including the International Sustainability and Carbon Certification Program (ISCC), incorporate methods to limit the negative effects of land use change. These certification standards must be updated

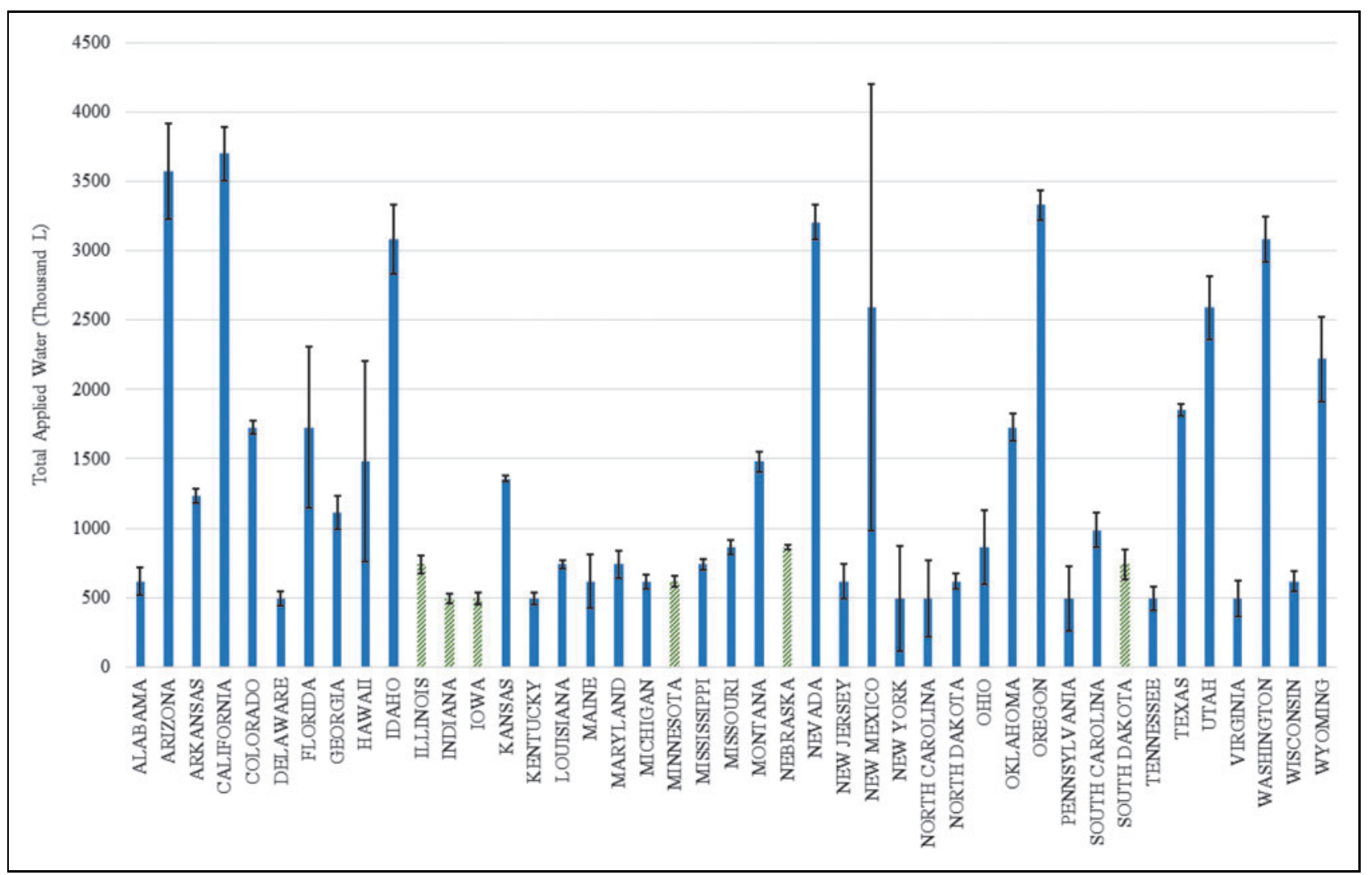

Fig. 1. Irrigation level for corn by state. Error bars represent coefficient of variation. Six top-producing states for corn indicated with green hashed bars. 


\section{INDUSTRY REACHES INFLECTION POINT}

as remote sensing and satellite technology continue to improve our ability to track and monitor land-use change. In the US, there are misconceptions that the use of corn for fuel impacts land use and food prices. ${ }^{32}$ Highlights from a study published in the journal Biomass and Bioenergy illustrate real-world data that show no evidence of food price increases or other lands converting to agriculture because of biofuel. ${ }^{33}$ In the US between 2000 and 2017, total field crop acres were actually down 9.5 million acres. Total crop acres have decreased while output has increased.

To-date, many LCAs show favorable comparisons between bioproducts and their fossil fuel-derived counterparts. Adom et al. carried out LCAs of eight bioproducts, including glycerol, lactic acid, propylene glycol, and 1,3-propanediol, which are shown in Table 2. The feedstock was either corn stover or algae. Life-cycle GHG emissions of the evaluated bioproducts were between $40-86 \%$ less than emissions for peer products made from fossil fuels (Fig. 2). ${ }^{34}$

In summary, LCA is a valuable tool to evaluate bioproduct sustainability at a systems level. Given the dependence of results on data sources and methodology choices including co-product handling, system boundary, and choice of spatial and temporal scale, bioproduct LCAs must be transparently documented to aid credibility. Further, bioproduct LCAs must account for the advancements in synthetic biology and dry milling technology and co-products which this paper describes to generate accurate results for corn sugar-derived bioproducts.

\section{Technoeconomic Models}

For biobased/sustainable processes, the input cost of raw materials is the largest factor in determining if a manufacturing process has viable economics compared to the traditional

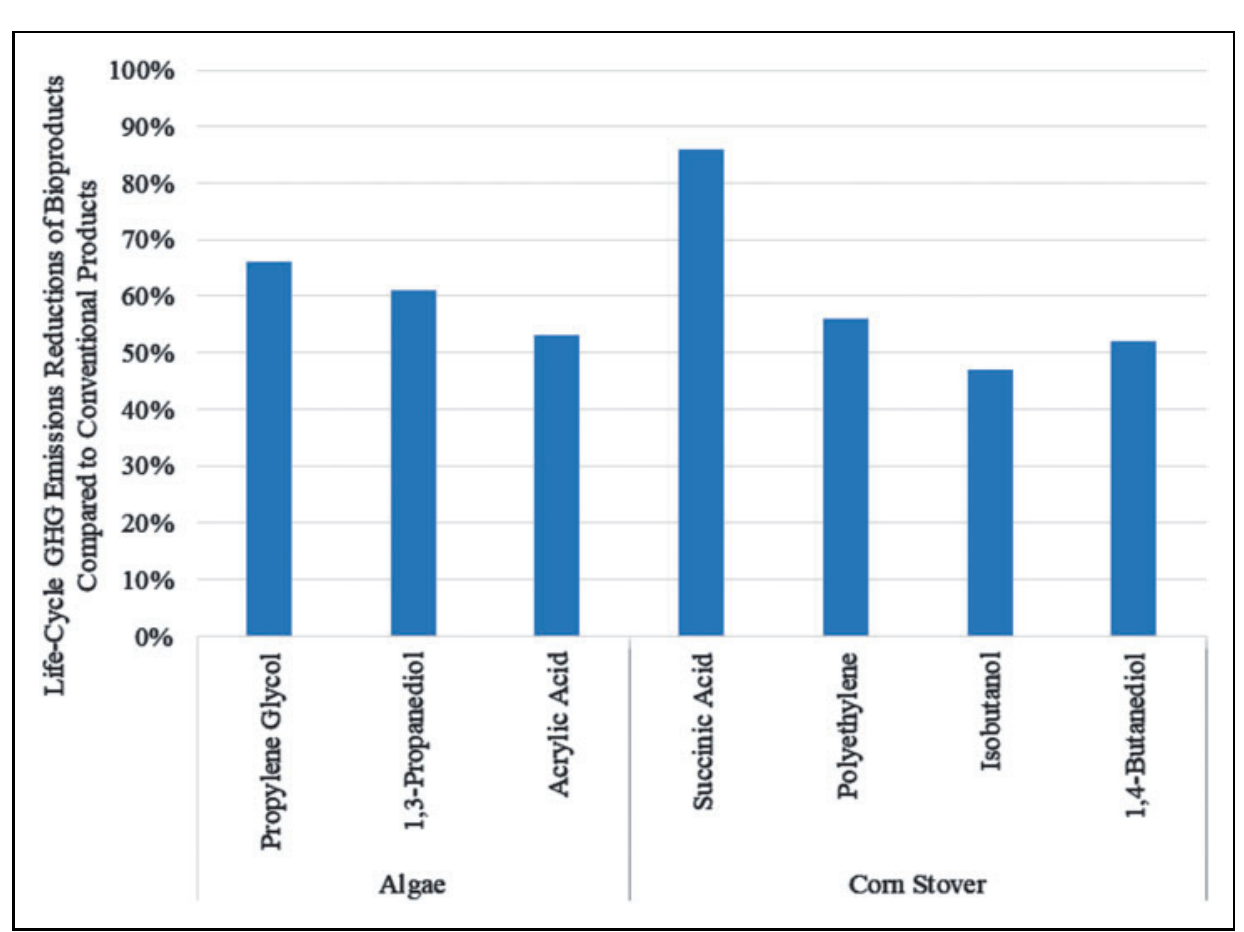

Fig. 2. Life-cycle GHG emissions reductions from bioproducts made from algae and corn stover compared to conventional products made from fossil fuels. petroleum-based materials. Generally, input materials (feedstocks) typically account for 70-75\% of the total cost of manufacturing for ingredients and products. This generality holds true for (net) corn cost to produce corn-derived sweeteners or for the dextrose cost in fermentation-based ingredients and materials. It thus becomes crucial for developers of new biobased technologies and ingredients to fully understand the supply and demand dynamics of the key raw materials being used and potential impacts to their market prices.

\section{DEMAND-SIDE CONSIDERATIONS}

As we move towards a circular economy and realize continued momentum in the "bio-revolution," the availability of economically advantaged carbohydrate sources will grow in importance as consumers seek products that are agriculturally based and not derived from petroleum. If we consider the total specialty chemical and materials market worth $\$ 480$ billion, a $25 \%$ penetration in specialty chemicals and a $10 \%$ penetration in further commodity categories would indicate a biobased market potential of $\$ 130$ billion over the next 10-20 years (Fig. 3). ${ }^{35}$ This market includes the rapidly expanding synthetic biology arena where the traditional viewpoint on how our food is made is being radically challenged. These developing opportunities are everyday consumer goods items, milk proteins, egg proteins, and non-animal-based leather being produced from fermentation processes - with sugar (glucose) being the raw material for these fermentation processes. Considering this new approach to our food supply chain of growing and pivoting away from petroleum, our calculations show the biobased market would require at a minimum an additional 14 billion pounds ( 315 million bushels of corn) annually of agriculturally based carbohydrates within the next 10-20 years.

\section{SUPPLY-SIDE CONSIDERATIONS}

When contemplating carbohydrate feedstock sources in the US, the major considerations are cane/beet sucrose, corn-based glucose/dextrose, and cellulosic derivatives. Due to US trade policy, market pricing of unrefined or refined sugar beet and sugar cane is elevated and the upper limit of availability is limited by quota. Thus, today and in the future, most all sucrose (table sugar) goes directly into final consumer goods and is not used in industrial or further processing applications. Cellulosic sugars (typically C5 and C6 sugars) have potential; however, large-scale production at economically viable costs has been elusive and may continue to be for at least the next decade. This brings us back to corn-based glucose, which is already the most widely used feedstock for advanced biobased processing and will continue to be expanded for the foreseeable future in the US. 


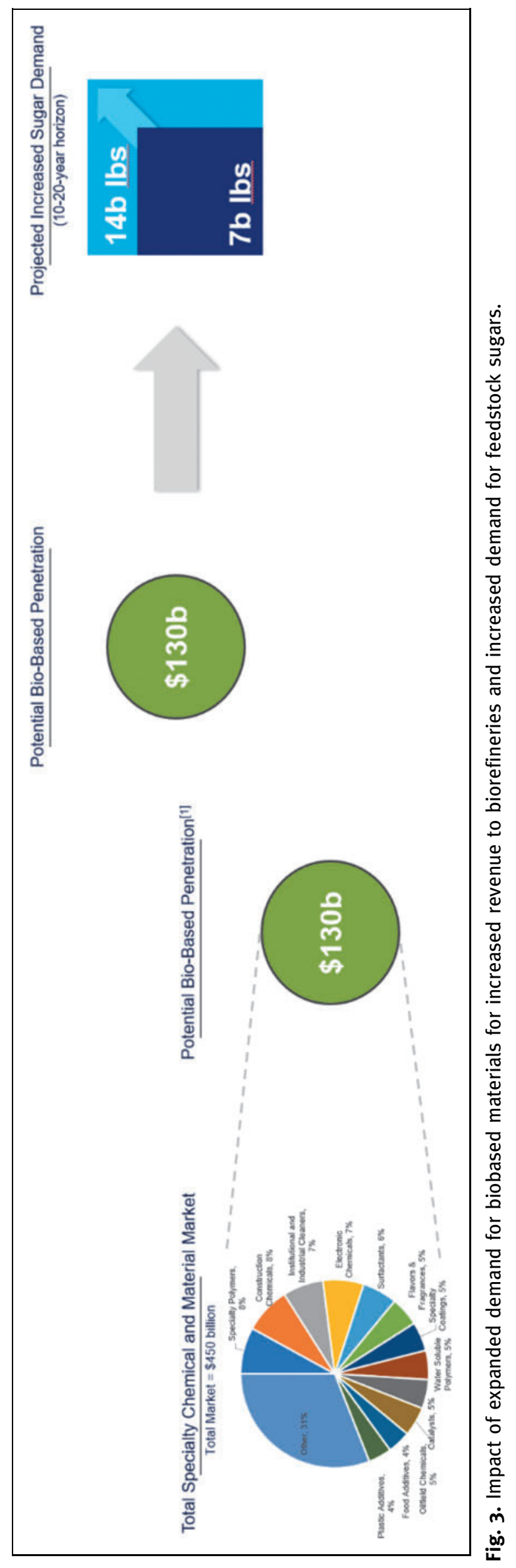

MARY ANN LIEBERT, INC. • VOL. 16 NO. 6 • DECEMBER 2020 INDUSTRIAL BIOTECHNOLOGY 327 


\section{INDUSTRY REACHES INFLECTION POINT}

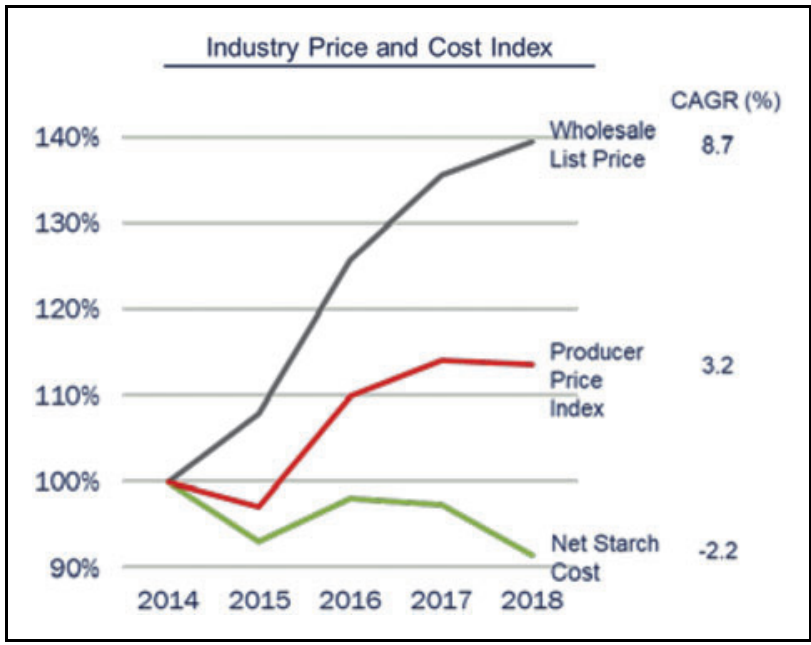

Fig. 4. Historical trends of market price and underlying production costs of corn-based glucose syrups. Significant change has occurred in the wholesale price while net starch cost has decreased.

\section{Supply Deficit Projected}

Over the past $30+$ years the corn wet milling industry has enabled large-

scale manufacturing of glucose syrups (Fig. 4). As these facilities have reached the limits of their scale economics and the recent consolidation of manufacturing sites (Cargill closure at Memphis, TN in 2014 and Ingredion closure of Stockton, CA in 2018) the market price of glucose has trended up.

The wet mill has and will continue to play a critical role in biobased industry as they continue to diversify and divert grind capacity made available from reduced high fructose corn syrup demand into new biobased manufacturing processes. Recent

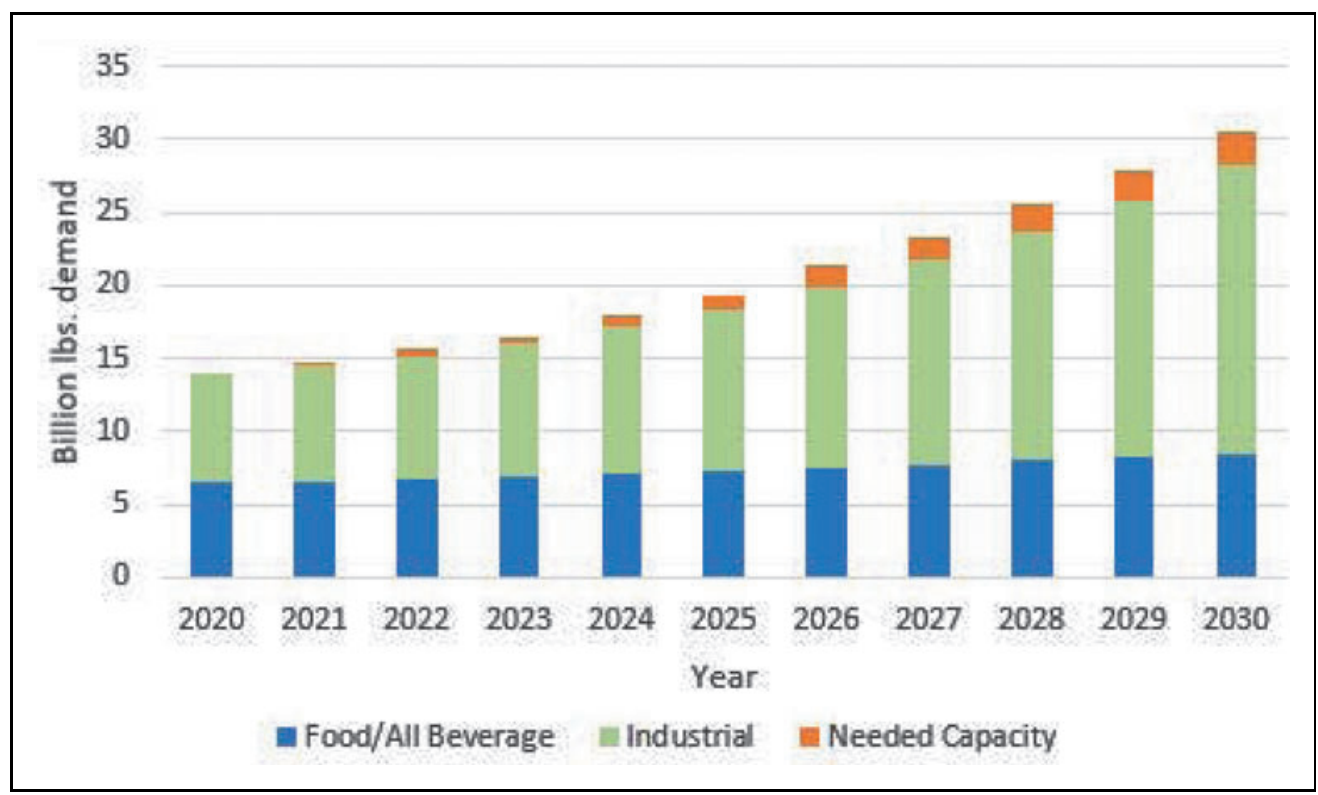

Fig. 5. 10-Year projection of total glucose demand with annual sugar short-fall for new uses noted in orange. examples of this include Cargill's exclusive license of Proctor and Gamble's bio-acrylic acid technology and subsequent investment in Eddyville, IA plant expansion. ADM's partnership to produce Spiber's Brewed Protein ${ }^{\mathrm{TM}}$ polymers is another example of the wet mills adjusting production. However, as we look at the total available capacity for carbohydrate feeds in the wet mill industry versus the projected demand, there is a shortage. As shown in Fig. 5, considering a continuation of declining high fructose corn syrup demand, there is a net deficit of glucose needed to support the growing industrial and further processing demand from biobased products. The cumulative supply gap over the next decade is in excess of 12 billion commercial basis (commercial basis is equivalent to $35 \mathrm{lbs}$ of starch per bushel of corn) pounds of glucose. By 2030, the deficit in that year alone is 2.3 billion c.b. (corn basis) pounds, which translates into 66 million bushels of corn base glucose annually.

\section{NEW SUPPLY SOURCES EMERGE}

To help fill this supply gap and further enable the economics of the growing biobased industry, new sources of glucose/ dextrose are emerging from the dry corn milling/ethanol industry. The dry mill industry has traditionally not been looked at as a source for carbohydrates to be supplied to the broader market. However, with 210 facilities and an annual combined corn grind capacity of more than 5.5 billion bushels, this source is being given significant new attention. However, to make this new supply source a reality, technologies are needed to unlock the dry mill sugar sources that have operating costs at or below that of the next best alternative.

When evaluating raw materials from a total operating cost perspective, one of the key drivers to having an attractive position is the net corn costs (NCC). NCC is defined as the cost of corn delivered to the processing facility less the value of all coproducts produced (essentially deriving a net starch cost). For the ethanol dry corn milling industry, NCC have continued to improve as corn oil recovery has increased and investments have been made in technologies to further separate apart the highly commoditized DDGS (dry distillers grains with solubles) stream into a more valuable high protein stream $(50$ $60 \%$ protein), with a more consistent corn fiber stream. The efforts to maximize co-product value combined with a cash corn cost advantage, driven by lower corn basis, has facilitated the dry mill industry to be a viable source of low cost carbohydrates helping to fill the glucose supply gap and stabilize market pricing.

Table 4 below shows the typical net corn cost for the wet mill (standard), a first-generation 


\begin{tabular}{|c|c|c|c|}
\hline NET CORN & WET MILL & $\begin{array}{c}\text { BASE } \\
\text { ETHANOL } \\
\text { PLANT }\end{array}$ & $\begin{array}{c}\text { TRUE } \\
\text { BIOREFINERY }\end{array}$ \\
\hline Corn cost $(\$ / b u)$ & $\$ 3.70$ & $\$ 3.60$ & $\$ 3.60$ \\
\hline $\begin{array}{l}\text { Co-Product credit } \\
(\$ / \text { bu) }\end{array}$ & $\$ 1.52$ & $\$ 1.13$ & $\$ 1.78$ \\
\hline $\begin{array}{l}\text { Cost of corn } \\
(\$ / b u)\end{array}$ & $\$ 2.18$ & $\$ 2.47$ & $\$ 1.82$ \\
\hline $\begin{array}{l}\text { Cost of Starch } \\
(\$ / \#)\end{array}$ & 0.066 & 0.077 & 0.056 \\
\hline
\end{tabular}

In this calculation, the co-products costs are deducted from the total corn cost. This adjusted cost of corn is then divided by number of pounds of starch remaining after processing.

ethanol dry mill compared to the existing and future biorefineries. These new integrated biorefineries focus on the full separation of the corn kernel either before ethanol fermentation or after, with the goal to maximize the individual stream components. This is no different than what the wet mills have been doing for the past $50+$ years. The separation technologies have advanced to allow those same (or better) co-product product yields and hence value that ultimately drives the cost of the starch/dextrose lower than what has been traditionally possible in the corn processing industry. Additionally, the smaller size of dry mill production will allow the glucose stream produced to be customized to end-user criteria.

The co-product credit is simply a calculation that takes the yield of each co-product multiplied by its value, converted to a dollar (\$) per bushel basis:

Base Dry Mill Plant NCC Calculation Example:

DDGS Yield (15.0 pounds per bushel) X DDGS Value ( $\$ 126.40$ per ton) $/ 2000$ pounds per ton $=\$ 0.948$ per bushel

Oil Yield ( 0.7 pounds per bushel) X Corn Oil Value (\$0.26 per pound $)=\$ 0.182$ per bushel

Total Co-Product Credit $=\$ 0.948+\$ 0.182=\$ 1.13$ per bushel value created

Higher efficiency yields and higher co-product values over time drive up the co-product credit and hence down the net corn cost, resulting in the lowest possible starch/sugar cost. The lower the cost of the starch, the more aggressively the bio-revolution will grow.

Additionally, as part of the cost-optimization process for industrial manufacturers, it is increasingly important to match raw material/feedstock supply quality with the minimum necessary requirements for the process. Minimal options exist today for different levels of refinement for glucose syrup supply in the marketplace. Refined glucose is the most widely marketed product with unrefined glucose having limited supply to the broad market with its supply typically limited to over-the-fence arrangements at wet mill facilities. There is an opportunity for

the new dry corn milling sources of glucose to be tailored to the quality of feedstock needed for industrial processes. An example of this tailoring is production of a partially refined product that removes impurities having a negative impact on the fermentation of downstream processes while keeping desirable components (e.g., minerals, micronutrients) that enhance productivity. A further opportunity is in alignment of an industrial (non-food) process with an industrial sugar source. Today, most supply is food-grade, which can exceed the requirements of most bioprocesses and inject unnecessary costs into the final product. Properly aligning these sorts of mismatches in needs to the minimum necessary requirements can be a critical enabler in pushing the biobased process to commercial viability, i.e., faster time-to-market for new products/processes.

As dry mill producers continue to grapple with over-capacity and low margins, they are looking for ways to diversify their revenue and the capacity to make glucose available to the broader market. This is a win for them, a win for the biobased industry, a win for the environment, and a win for society as a whole. New, commercially ready technologies for glucose supply need to be a part of all biobased manufacturer economic evaluation. These options will serve as the catalyst to lower the activation energy for the next generation of technologies to accelerate the bio-revolution towards a more circular economy (Table 5).

\section{Potential for Economic Impact}

Biorenewables have a unique economic impact. They create value across geographies, employment sectors, and markets. Consider DuPont's 1,3-PDO; research and Development of 1,3PDO was conducted by researchers in California, Illinois, Tennessee and Delaware. Production of this molecule creates a

Table 5. Analysis of Key Drivers That Will Impact the Type and Production of Sugars for Conversion into Biobased Chemicals

DEMAND-SIDE

CONSIDERATIONS

- Move toward circular economy

- Consumer movement toward biobased products

- Total specialty chemicals and materials market worth $\$ 450$ billion; 25\% penetration in specialty chemicals and $10 \%$ penetration in further commodity categories $=$ biobased market potential of $\$ 130$ billion

- Rapidly expanding synthetic biology arena

- Biobased market over next 10-20 years will require at least 14 billion pounds (315 million bushels of corn)
SUPPLY SIDE

CONSIDERATIONS

- Major carbohydrate sources: cane/beet sugar, corn-based glucose/ dextrose, and cellulosic derivatives

- Quota restrictions, market pricing and US trade policy availability of cane/beet sugar is limited.

- Cellulosic sugars not yet economically viable at large-scale production

- Corn-based glucose is most widely used feedstock for advanced bio-based processing and will continue to be expanded for the foreseeable future in the US

- Deficit of 2.3 billion pounds of glucose expected in 2030

- New sources of glucose/dextrose emerging from dry mill industry as plants diversify 


\section{INDUSTRY REACHES INFLECTION POINT}

new market for Midwestern corn that is shipped to Louden, TN where it is converted into 1,3-PDO and feed products. PDO is then shipped globally, where it is used in several different markets from humectants to heat transfer fluid. Its largest market, however, is in high-value fiber. For this application, PDO is shipped to Kinston, NC where it is converted to Sorona ${ }^{\circledR}$ pellets to be transformed into fibers globally.

Not only do biorenewables create a myriad of jobs across a wide range of geographies, these jobs also tend to pay significantly more than the US national average (Table 6). The 2016 study "Investment, Innovation, and Job Creation in a Growing U.S. Bioscience Industry" found that the average salary in industrial biosciences was $62 \%$ higher than the overall US average for salaries. ${ }^{36}$

Further, jobs within the biotech sector are growing quickly. The 2016 study also indicated that US job growth in the biosciences grew by $18.6 \%$, compared to $9.8 \%$ for total private sector jobs during 2001-16. Finally, many of these jobs are in rural areas, addressing these region's challenges in job creation. So, industrial biotech is not only a rapidly growing sector, it also offers highpaying jobs for a range of geographies including rural economies. The findings of this study are comparable those of a 2016 Europa Bio analysis that estimates up to $8.4 \%$ increase annually in jobs in the industrial biotechnology sector through 2030. ${ }^{37}$

The biobased products sector has a national impact. A report from USDA's Biopreferred Program indicates biobased products contributed \$459 billion to the US economy in 2015-2016 (USDA-RDS) ${ }^{38}$ Growth in the bioproducts sector led to a total of 4.65 million jobs in 2016 while the growing bioeconomy led to an estimated reduction of GHG emissions by $60 \%$ with "analyses indicating that up to 12 million metric tons of $\mathrm{CO}_{2}$ equivalents may have been reduced in 2016."

The industrial biotech sector has significant collateral benefits. The Europa Bio study finds that more than one third or $€ 38.6$ billion of the $€ 92.8$ billion in revenue generated by industrial biotech is captured in the production of feedstock. Given the distributed nature of renewable feedstock, this means a large number of feedstock producers are able to participate in the value created.

\section{What Is Needed to Drive Industry Forward}

While the technology is developing at a rapid pace, sustainable, biobased materials still face challenges to unlock their economic power to create jobs, open sizable new markets for agricultural feedstocks and grow the circular economy. The

\section{Table 6. Comparison of Annual Salaries by Sector}

EMPLOYMENT SECTOR

\begin{tabular}{l|c}
\hline Industrial Biosciences & $\$ 80,961$ \\
\hline Manufacturing & $\$ 64,860$ \\
\hline Construction & $\$ 58,643$ \\
\hline Real Estate & $\$ 54,959$ \\
\hline Average All Jobs & $\$ 50,001$ \\
\hline
\end{tabular}

Table 7. Needs Across the Stages of Research, Development and Commercialization for Industrial Biotechnology and Suggestions on Specific and General Policies to Address These Needs

RESEARCH NEEDS

HOW TO ACHIEVE

\begin{tabular}{l|l}
$\begin{array}{l}\text { Expand and increase speed of } \\
\text { technology innovation }\end{array}$ & $\begin{array}{l}\text { - Expand DOE BETO Funding of } \\
\text { research using commercially available } \\
\text { feedstocks } \\
\text { - Increase USDA extramural funding }\end{array}$ \\
\hline
\end{tabular}

\section{DEVELOPMENT NEEDS}

\begin{tabular}{l|l}
\hline Access to scale up facilities & $\begin{array}{l}\text { - Leverage first generation bioethanol } \\
\text { production facilities }\end{array}$ \\
\hline Decrease time to market for innovation & $\begin{array}{c}\text { - Facilitate increased technology } \\
\text { transfer from government labs } \\
\text { - Increased access to government } \\
\text { research labs and pilot facilities }\end{array}$ \\
\hline Support for entrepreneur and startups & $\begin{array}{c}\text { - Ongoing funding for USDA Rural } \\
\text { Development of the Intermediary } \\
\text { Relending Program }\end{array}$ \\
\hline $\begin{array}{l}\text { Assist in the development, construction } \\
\text { and retrofitting of new and emerging } \\
\text { technologies }\end{array}$ & $\begin{array}{c}\text { - Section 9003 Biorefinery, Renewable } \\
\text { Chemical, and Biobased Product } \\
\text { Manufacturing Assistance Program }\end{array}$ \\
\hline
\end{tabular}

\begin{tabular}{|c|c|}
\hline \multicolumn{2}{|l|}{ COMMERCIALIZATION NEEDS } \\
\hline De-risk and Increase speed to market & $\begin{array}{l}\text { - Support of USDA BioPreferred } \\
\text { - Public Private Partnerships }\end{array}$ \\
\hline $\begin{array}{l}\text { Reduce barriers to market entry and } \\
\text { de-risk capital }\end{array}$ & - National and State Incentives \\
\hline Address circular economy & $\begin{array}{l}\text { - Developed closed loop processes } \\
\text { - Expand material collection, reuse, } \\
\text { recycling and composting } \\
\text { infrastructure }\end{array}$ \\
\hline Standardized life cycle assessment & $\begin{array}{l}\text { - Bring stakeholders together to agree } \\
\text { on common format, definitions, } \\
\text { metrics and scope }\end{array}$ \\
\hline Capital for new processes or new plants & $\begin{array}{l}\text { - Increase EB-5 loan opportunities for } \\
\text { rural production facilities } \\
\text { - Support for USDA Rural Development } \\
\text { Business \& Industry Program } \\
\text { - Expand } 9007 \text { (REAP) Program }\end{array}$ \\
\hline Human capital development & - Support for training of employees \\
\hline Increase market pull & $\begin{array}{l}\text { - Plant-based product labeling } \\
\text { initiative }\end{array}$ \\
\hline
\end{tabular}

biggest enabler of these products and technologies will be customer and consumer pull created in the marketplace. Recent studies find an increasing number of consumers are demanding more sustainable solutions post COVID-19, making a connection between personal and environmental health. These products need to offer equal or better performance and sustainability versus an incumbent product. Furthermore, $78 \%$ of consumers thought companies should be doing more to help them make 
sustainable decisions and $65 \%$ of this group wanted a clear explanation of the benefits. ${ }^{4}$

To address these needs and help develop consumer pull, a plant-based product labeling initiatives like the EnergyStar program should be developed. EnergyStar has demonstrated how a government-backed program on energy efficiency has enabled consumers to make better choices to save over $\$ 35$ billion in energy while helping to develop and support a competitive manufacturing ecosystem supporting hundreds of thousands of jobs. ${ }^{39} \mathrm{~A}$ similar approach for plant-based products could be very impactful for a more rapid, fact-based consumer adoption and long-term demand creation.

To this end, the BioPreferred program is a valuable program that should continue to be fully funded. The Rural Development 9007 Rural Energy for America Program is another program for commercial renewable energy systems and energy-efficiency improvement projects that should be continued as well as the Business \& Industry Program for larger business loan guarantees. Furthermore, there is opportunity for industry and organizations to push for a national incentive program that would prove valuable when layered on top of state incentives for biobased production. These incentives are crucial for commercialization of biobased products in a time when oil prices are low and capital expenditure is risky.

In addition to consumer pull, development programs, and incentives, biobased manufacturing and technology sectors need assistance to help prioritize and align technology readiness throughout the value chain. A stronger connection between feedstock, conversion technology and end applications are needed to help enable sustainable platform technologies. Creation of new public-private partnerships could help accelerate and de-risk initiatives to the benefit of taxpayers and the bioeconomy. For example, the European Union and the Bio-Based Industries Consortium (BIC) created the Biobased Industries Joint Undertaking (BBI-JU). They have funded 123 biobased innovation projects with 924 beneficiaries with $€ 3.7$ billion ( $€ 1$ billion public, $€ 2.8$ billion private) from $2014-2020$. These projects are focused on three main areas: feedstock, biorefineries, and markets; products; and policies. ${ }^{40}$ Connecting value chain partners and leveraging investment through public-private consortiums can help de-risk and accelerate commercialization, stimulate job creation and generate demand pull from end markets for plant-based products.

On the research side, support of initiatives on broad technology platforms can benefit a range of technologies. Ongoing funding of DOE programs, including BioFoundries, Carbon Dioxide Utilization and Biochemical Conversion Programs, will benefit a wide range of industries. When leveraging firstgeneration bioethanol production facilities, federal agencies should decouple feedstock development from product development risk. Utilizing commercially available feedstocks, such as corn starch and fiber, is a step in the right direction. Two areas of additional research for consideration are:

1. Better enzymes to degrade corn fiber

2. Separation of pentose sugars from hexose sugars, which may allow access to higher value markets like xylitol and furan derivatives.
The United States Department of Agriculture (USDA) is also an important research partner and many of the USDA Agricultural Research Service (ARS) National Laboratories have opportunities to utilize extramural funding for research and capabilities to outreach to innovative companies. On the development side, ongoing USDA ARS technology transfer efforts are necessary. Furthermore, USDA Rural Development has various program offerings including Section 9003 Biorefinery and Renewable Chemical Loan Program for new, innovative and first of their kind biofuels, renewable chemicals, and biobased product manufacturing projects. In addition, the Intermediary Relending Program is a tool for entrepreneurs and startups to utilize for smaller projects.

Finally, as biobased, circular solutions are developed, more support and investments are needed for collection, reuse, recycling and or composting of these materials. While this issue is important to the entire circular economy, the need for appropriate collection, recycling and composting systems is paramount to unlock the benefits for both plant-based direct replacements of petrochemicals and new bio-advantaged and biodegradable offerings. This is also a new growth area for the economy that can generate new jobs and investment at the local, state and national level. ${ }^{41}$ Composting will not only benefit biodegradable packaging materials, but is a key pillar of the EPA to help reduce impact of wasted food to improve soil health. ${ }^{42}$ A systems approach to collecting and composting food waste and biodegradable packaging together offers a substantial opportunity to avoid landfills, improve soil health and lower greenhouse gas emissions.

\section{Acknowledgments}

M.C.J. acknowledges support from the Department of Energy Grant DE-SC0018249, the DOE Joint Genome Institute ETOP program, and the Office of Energy Efficiency and Renewable Energy Grant DE-EE0008343.

Nathan Danielson is principal at BioCognito, a Pleasanton, California-based firm assisting companies in the agricultural and industrial biotechnology spaces bring their technology successfully to market. He is also a former program manager at DuPont Applied Sciences. Phone: (925) 523 3751. E-mail: nathan.danielson@ gmail.com.

\section{REFERENCES}

1. Werpy T, Petersen G. Top Value Added Chemicals From Biomass Volume 1: Results of Screening for Potential Candidates from Sugars and Synthesis Gas (2004). Available at: https://nrel.gov/docs/fy040sti/35523.pdf (Last accessed November 2020).

2. Hou J, Shanks BH. Bioprivileged molecules: Integrating biologial and chemical catalysis for biomass conversion Ann Rev Chem Biomol Eng 2020;11(4):63-85.

3. Wang LW, Nehring R, Mosheim R. US Department of Agriculture Economic Research Service. Agricultural Productivity Growth in the United States: 1948-2015 (2018). Available at: https://ers.usda.gov/amber-waves/2018/march/ agricultural-productivity-growth-in-the-united-states-1948-2015/ (Last accessed Nov 2020)

4. Kearney. Consumer Support Still Strong as Earth Day Celebrates its $50^{\text {th }}$ Birthday (2020) Available at: https://kearney.com/consumer-retail/article/?/a/ consumer-support-still-strong-as-earth-day-celebrates-its-50thbirthday\&tutm_medium=email\&utm_source=vuturethankyoupage\&utm_ campaign = 2020AmericasEarthDay (Last accessed September 2020) 


\section{INDUSTRY REACHES INFLECTION POINT}

5. National Human Genome Research Institute. The Cost of Sequencing a Human Genome (2019) Available at: https://genome.gov/about-genomics/fact-sheets/ Sequencing-Human-Genome-cost (Last accessed July 2020).

6. Swartz JR, Shanks BH, Dumesic JA. Coupling chemical and biological catalysis: A flexible paradigm for producing biobased chemicals. Curr Opin Biotechnol 2016;38:54-62.

7. Karp EM, Eaton TR, Nogue VS, et al. Renewable acrylonitrile production. Science 2017;358: 1307-1310.n

8. US Department of Agriculture Economic Research Service. Fertilizer Use and Price Database. Available at: https://ers.usda.gov/data-products/fertilizer-useand-price/ (Last accessed September 2020)

9. Bloch $S E$, Clark R, Gottlieb SS, et al. Biological nitrogen fixation in maize: Optimizing Nitrogenase expression in a root-association Diazotroph. $J$ of Exp Bot 2020;71(15):4591-4603.

10. Renewable Fuels Association, Ethanol Biorefinery Locations. Available at: https://ethanolrfa.org/biorefinery-locations (Last accessed November 2020)

11. De Jong E, Stichnothe H, Bell G, Jorgensen H. Bio-Based Chemicals A 2020 Update IEA BioEnergy Available at: https://ieabioenergy.com/wp-content/ uploads/2020/02/Bio-based-chemicals-a-2020-update-final-200213.pdf (Last accessed October 2020)

12. Zhou X, Brentzel J, Kraus G, et al. Computational framework for the identification of bioprivileged molecules. ACS Sustainable Chem Eng 2018;7(2):2414-2428.

13. Wu W, Long MR, Zhang X, Reed JL, Maravelias CT. A Framework for the identification of promising bio-based chemicals. Biotechnol Bioeng 2018; 115(9):2328-2340.

14. Kim GB, Kim WJ, Kim HU, et al. Machine learning application in systems metabolic engineering. Curr Opin Biotech 2020;64:1-9.

15. Silverman AD, Karim AS, Jewett MC. Cell-free gene expression: An expanded repertoire of applications. Nat Rev Genet 2020;21:151-170.

16. Dudley QM, Karim AS, Jewett MC. Cell-free metabolic engineering: Biomanufacturing beyond the cell. Biotechnol J 2015;10:69-82.

17. Karim AS, Dudley $Q M$, Juminaga $A$, et al. In vitro prototyping and rapid optimization of biosynthetic enzymes for cell design. Nature Chem Bio 2020;16: 912-919.

18. Dudley QM, Karim AS, Connor J, et al. Cell-free prototyping of limonene biosynthesis using cell-free protein synthesis. Metabol Eng 2020;61:251-260.

19. Syngenta Enogen Corn Website. Available at: https://syngenta-us.com/corn/ enogen (Last accessed October 2020).

20. Chen $X$, Yin J, et al. Halomonas bluephagenesis TBO1 for Non-sterile Production of Poly(3-hydroxybutyrate-co-4-hydroxyburyrate). Bioresour Technol 2017; 244(1):534-541.

21. Cortright R. NREL, Personal Communication Sept. 2020

22. Swartz JR. Transforming biochemical engineering with cell-free biology. AIChE 2011;58(1):5-13.

23. Bowie JU, Sherkhavnov S, Korman TP, et al. Synthetic biochemsitry: The bioinspired cell-Free approach to commodity chemical production. Trends Biotechnol 2019;38(7):766-778.

24. Grubbe WS, Rasor BJ, Kruger A, et al. Cell-free styrene biosynthesis at high titers. Metabol Eng 2020;61:89-95.
25. Kay JE, Jewett MC. Lysate of engineered Escherichia coli supports high-level conversion of glucose to 2,3-Butanediol. Metab Eng 2015;32:133-142.

26. Dunn JB. Biofuel and bioproduct environmental sustainability analysis. Curr Opin Biotechnol 2019;57:88-93.

27. Qin Z, Canter CE, Dunn JB, et al. Land management change greatly impacts biofuels' greenhouse gas emissions. GCB Bioenerg 2018;10: 370-381.

28. Cai $H_{1}$ Han J, Wang $M$, et al. Life-cycle analysis of integrated biorefineries with co-production of biofuels and bio-based chemicals: Co-product handling methods and implications. BioFPR 2018; doi:10.1002/bbb.1893.

29. Benavides PT, Dunn JB, Han J, et al. Exploring comparative energy and environmental benefits of virgin, recycled, and bio-derived PET bottles. ACS Sust Chem Eng 2018;6:9725-9733.

30. U.S. Department of Agriculture Economic Research Service. Irrigation and Water Use. Available at: https://ers.usda.gov/topics/farm-practices-management/ irrigation-water-use/\#where (Last accessed November 2020)

31. Qin Z, Dunn JB, Kwon H, et al. Influence of spatially-dependent, modeled soil carbon emission factors on life-cycle greenhouse gas emissions of corn and cellulosic ethanol. GCB Bioenerg 2016;6:1136-1149.

32. Dunn JB, Katsaggelos $A$, Mueller $S$, et al. Interdisciplinary collaboration for timely, accurate, policy-relevant land use and land cover change estimates. Environ Res Lett 2020; under review.

33. Shrestha DS, Staab BD, Duffield JA. Biofuel impact on food prices index and land use change. Biomass Bioenerg 2019;124:43-53.

34. Adom A, Dunn JB, Han J, Sather N. Life-cycle fossil energy consumption and greenhouse gas emissions of bioderived chemicals and their conventional counterparts. Environ Sci Technol 2014;48:14624-14631.

35. Singh V, Stone J, Roberts JP, et al. Industrial biotechnology shaping corn biorefineries of the future. Cereal Foods World 2019;64(4).

36. TEConomy Partners LLC., Biotechnology Innovation Organization. Investment, Innovation and Job Creation in a Growing U.S. Bioscience Industry (2018). https://bio.org/value-bioscience-innovation-growing-jobs-and-improvingquality-life-2018 (Last accessed September 2020)

37. Europa Bio. Jobs and Growth Generated by Industrial Biotechnology in Europe (2016). Available at: https://europabio.org/industrial-biotech (Last accessed September 2020).

38. U.S. Department of Agriculture Rural Development. An Economic Impact Analysis of the US Biobased Products Industry (2018) Available at: https:// biopreferred.gov/BPResources/files/ BiobasedProductsEconomicAnalysis2018.pdf (Last accessed September 2020)

39. Energy Star Website. Available at: energystar.gov/about (Last accessed October 2020)

40. Bio-Based Industries. Available at: bbi-europe.eu (Last accessed October 2020).

41. Eco-Cycle Solutions Website: www.ecocyclesolutionshub.org (Last accessed Oct 27,2020)

42. US Environmental Protection Agency. Reducing the impact of wasted food website. Available at: https://epa.gov/sustainable-management-food/reducingimpact-wasted-food-feeding-soil-and-composting (Last accessed October 2020). 